J. Membrane Biol. 122, 189-192 (1991)

$002226319100092 \mathrm{C}$

Membrane Biology

O Springer-Verlag New York Inc. 1991

In Memory of

Salvador E. Luria 


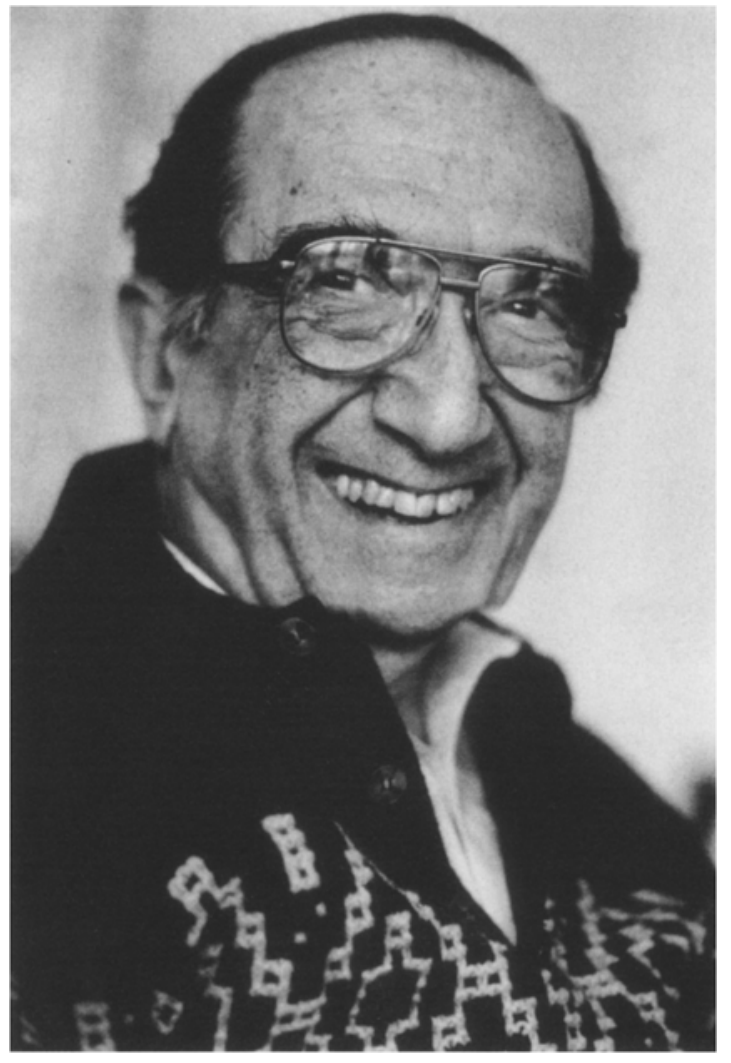

MIT Photo by

Donna Coveney 


\title{
Salvador E. Luria (1912-1991), a Unique Human Being
}

\author{
“Any biography worth reading should ideally tum around a personality, not around a 'poet,' a 'painter,' \\ or a 'scientist.' \\ To examine Pasteur without his roots in French provincial bourgeois life or Einstein without his relation \\ to Judaism is to diminish them."
}

\author{
S.E. Luria \\ "A Slot Machine, A Broken Test Tube" \\ An autobiography \\ (Harper \& Row, New York, 1984)
}

S.E. Luria was born in Turin, Italy, in 1912 and died in Boston on February 6, 1991. He was a brilliant scientist who turned the neglected bacteriophages into an important quantitative tool for genetic studies. He reported the first clear evidence for gene mutations in bacteria. Once when he broke a test tube containing $E$. coli, he turned to a strain of Shigella and discovered the phenomenon of restriction and modification. A modified phage that no longer could grow in E. coli, grew in Shigella. These observations eventually led to the discovery of restriction enzymes, an essential tool in the development of recombinant DNA technology.

Together with Max Delbrück and Al Hershey, he started the "phage group" with its seat in Cold Spring Harbor, famous for hosting great symposia. The phage group kept growing, soon reaching several hundreds who came to Mecca for the phage symposia.

An innovative idea generated by Luria and Delbrück was to exchange experimental data distributed as pamphlets within the phage group before they were ripe for publication. It generated, due to the forceful personalities of the two leaders, a communal spirit of sharing and enthusiasm with little or no abuse. This successful experiment has never been repeated.

Luria was a powerful personality, a curious mixture of arrogance and humility. Many knew of the former, few of the latter. I was fortunate to spend several summers in Cold Spring Harbor in the late forties. I saw Luria's arrogance, his humility, and his restlessness. While Delbrück would sit for hours as a model for several portraits, attempts with Luria were dismal failures. I could not cope with the restlessness of his face and body. I also saw his remark- able self-confidence. One evening I performed a "mind reading" trick that allows me to identify an object in the room selected by the audience in my absence. I had done this for many audiences before, but never did somebody get up and say "I can do this, too." Luria said it, and did it with supreme selfconfidence. Yet, Luria had humility. He rejected the image of an Italian macho and emphasized to journalists that he received the news of his Nobel prize award while washing the breakfast dishes. Once, when he stayed in our home in Ithaca, he insisted on making a special breakfast for us. He did not want to be treated as a Nobel laureate. He wanted to be known as a political activist and was not always patient with objections to his views. He seemed almost proud of having been put on the NIH blacklist.

Like many other scientists who fled from totalitarian countries in Europe, he was sensitive to any form of dictatorship even if it came from an American president. He was an antiwar activist and only reluctantly acknowledged the just cause of World War II. He was passionately engaged in antiwar activities during the Vietnam war, using advertisements in the New York Times and other newspapers co-signed by hundreds of eminent scientists and nonscientists. They were inexpensive and effective. In other areas he lost friends and gained enemies by his aggressive fights. It is ironic that a man who contributed so much to genetics, rejected its role in intelligence. His emotional involvement in the cause of socialism did not allow him to accept what is inevitable, a role of genes in all bodily functions, including those of the brain.

Luria did not hide his weaknesses, and his humanity emerged best in his style of working. He 
described in his autobiography his style of work as "uneven, reflecting my own ready alterations of moods, from excited and aggressive, to selfdoubting and despondent." What a great admission for our young scientists to hear!

He belittled the uniqueness of most scientific contributions of his own and of others. He wrote, "If Watson and Crick had not discovered the double helix structure for DNA it would probably have been discovered by someone else within a few months. The only difference would have been that 'The Double Helix,' the book by Watson, would not have appeared. Likewise, if I had not discovered restriction and modification of bacteriophage, they would have been discovered elsewhere within a few months." Probably not many among us agree with this view, but it emphasizes his wish to be recognized as a unique person rather than as a unique scientist. He was indeed unique in his friendships, in his rebellion, in his almost aggressive integrity, in his total rejection of TV (he watched it once), in his style of teaching and in his ability to inspire students. It is not an accident that two of them, Jim Watson and Renato Delbecco were recipients of the Nobel prize. He wanted recognition for his wife Zella, his "unique life partner" to whom he dedicated his award winning book, "Life, The Unfinished Experiment." The last brief chapter in his autobiography on emotions should be read by every person who knows of the chains of depression.

We want to pay tribute to Salvadore E. Luria, a unique human being, a great scientist and an inspiring teacher.

\author{
Efraim Racker \\ Section of Biochemistry, \\ Molecular and Cell Biology \\ Division of Biological Sciences \\ Cornell University \\ Ithaca, New York 14853
}

